\title{
Methane and carbon dioxide emissions from closed landfill in Taiwan
}

\author{
I-Chu Chen, Ullas Hegde, Cheng-Hsiung Chang, Shang-Shyng Yang * \\ Institute of Microbiology and Biochemistry, and Department of Biochemical Science and Technology, National Taiwan University, Taipei 10617, Taiwan
}

Received 29 March 2007; received in revised form 16 August 2007; accepted 16 August 2007

Available online 1 October 2007

\begin{abstract}
The atmospheric concentrations and emission rates of $\mathrm{CH}_{4}$ and $\mathrm{CO}_{2}$ were studied at three sites of the Fu-Der-Kan closed landfill and after as the multi-use recreational park in northern Taiwan. Atmospheric $\mathrm{CH}_{4}$ and $\mathrm{CO}_{2}$ concentrations of closed landfill were 1.7-4.6 and 324-409 ppm, respectively. $\mathrm{CH}_{4}$ and $\mathrm{CO}_{2}$ emission rates ranged from 8.8 to $163 \mathrm{mg} \mathrm{m}^{-2} \mathrm{~h}^{-1}$ and from 495 to $1531 \mathrm{mg} \mathrm{m}^{-2} \mathrm{~h}{ }^{-1}$, respectively. Diurnal variation was noted with higher values at night than those in daytime. After creation of the park, atmospheric $\mathrm{CH}_{4}$ and $\mathrm{CO}_{2}$ concentrations were 1.8-3.1 and 332-441 ppm, respectively. $\mathrm{CH}_{4}$ and $\mathrm{CO}_{2}$ emission rates ranged from -1.1 to $2.3 \mathrm{mg} \mathrm{m}^{-2} \mathrm{~h}^{-1}$ and from -135 to $301 \mathrm{mg} \mathrm{m}^{-2} \mathrm{~h}^{-1}$, respectively. There were no notable diurnal variations in either atmospheric concentrations or emission rates.
\end{abstract}

(C) 2007 Elsevier Ltd. All rights reserved.

Keywords: Landfill; Greenhouse gas; FTIR; Flux; Diurnal variation

\section{Introduction}

Landfills are accounting for about $10-19 \%$ of annual global $\mathrm{CH}_{4}$ emissions (Kumar et al., 2004; USEPA, 2006). The global warming potential of $\mathrm{CH}_{4}$ is 23 times higher than that of $\mathrm{CO}_{2}$ (USEPA, 2002). The atmospheric $\mathrm{CH}_{4}$ concentration has been increasing at a rate of -0.2 $1 \% \mathrm{y}^{-1}$ (Simpson et al., 2006). On a global scale, approximately $653 \mathrm{Tg} \mathrm{y}^{-1}$ of waste is landfilled, and annual global $\mathrm{CH}_{4}$ emissions from landfills range from 16 to $223 \mathrm{Tg}$ (Bogner and Matthews, 2003; Simpson et al., 2006).

Landfilling and incineration are the major methods of waste disposal in Taiwan. $89 \%$ of waste was disposed by landfills in 1989. This percentage dropped to $11.2 \%$ in 2006 as the result of increased incineration and the resource recycling policy (EPA/Taiwan, 2007). Landfills function as bioreactors due to the controlled and managed burial of biodegradable organic materials. These organic materials decompose via a complex series of microbial reactions

\footnotetext{
* Corresponding author. Tel.: +8862 23621519; fax: +886223679827.

E-mail address: ssyang@ntu.edu.tw (S.-S. Yang).
}

under anaerobic conditions. Eventually, they are converted into $\mathrm{CO}_{2}, \mathrm{CH}_{4}, \mathrm{~N}_{2} \mathrm{O}$ and $\mathrm{H}_{2} \mathrm{O}$. Landfill $\mathrm{CH}_{4}$ and $\mathrm{CO}_{2}$ generations are controlled by landfill management, cover soil, composition, temperature, pressure, moisture content, water table level, wind induced ebullition and $\mathrm{pH}$ of the refuse (Bogner and Matthews, 2003; Hegde et al., 2003). Methanogenesis in landfills occurs when the $\mathrm{pH}$ of organic waste is between 6.8 and 7.4 and it is stimulated by increasing moisture content (Jang and Yang, 2001).

The Fu-Der-Kan landfill site was closed in 1995, and a multi-use recreational park was constructed from 1999 to 2003. The soil surface is covered with grass and small trees. Although the $\mathrm{CH}_{4}$ and $\mathrm{CO}_{2}$ emission rates of active landfills are well documented (Bogner et al., 1999; Czepiel et al., 2003; Meraz et al., 2004), emissions from closed sites and sites which have been converted to park have not been investigated in detail.

Atmospheric $\mathrm{CH}_{4}$ and $\mathrm{CO}_{2}$ concentrations and emission rates from an active landfill in northern Taiwan were described in a previous study (Hegde et al., 2003). Two main methods are used for such measurements. Gas-type open-path Fourier-transform infrared (FTIR) spectroscopy has the advantages of good precision, rapid and 
simultaneous measurement of different volatile compounds, and the ability to cover long-distance. Chamber techniques can be used to measure $\mathrm{CH}_{4}$ and $\mathrm{CO}_{2}$ emission rates from small areas, typically less than $1 \mathrm{~m}^{2}$ (Yang and Chang, 1997). The advantages include simplicity, an appropriate scale for concurrent measurement of controlling variables, and the ability to determine the heterogeneity of surface emissions. Chamber techniques can also be easily compared to results from other studies because these methods have been widely employed in non-landfill settings for a variety of greenhouse gases (Rolston, 1986; Yang and Chang, 1998, 2001; Chang and Yang, 2003). In this study, FTIR was used successfully, along with gas chromatography (GC), to monitor atmospheric greenhouse gases. The atmospheric concentrations and emission rates of $\mathrm{CH}_{4}$ and $\mathrm{CO}_{2}$ were measured at Fu-Der-Kan closed landfill and after the construction of a multi-use recreational park in northern Taiwan.

\section{Materials and methods}

\subsection{Site description}

The Fu-Der-Kan landfill $\left(25^{\circ} 01^{\prime} 53.9^{\prime \prime} \mathrm{N}, 120^{\circ} 3^{\prime} 33.8^{\prime \prime} \mathrm{E}\right)$ is located near Taipei City in northern Taiwan. This landfill was opened in 1985 for municipal solid waste (MSW) dumping, closed in 1995 and converted to a multi-use recreational park during 1999 to 2003. It covers 98 ha and 37 ha were used for landfilling of MSW. It received $3200 \mathrm{t}$ of MSW every day during the operation period, with an average burial depth of $22.9 \mathrm{~m}$. The landfill was covered by 1$2 \mathrm{~m}$ of waste landfill soil as surface material. Upon closing, the landfill was covered with another $1-1.5 \mathrm{~m}$ of loam-clay loam soil and reconstructed as a multi-use recreational park in 2001 (Fig. 1). The test areas cover about 32 ha of landfilling area including areas A, B, C, E, F, G and part of $\mathbf{J}$ around the testing areas. Site $\mathrm{C}$ is younger than sites $\mathrm{A}$ and B. Site C had received new MSW in 1999. During 1999-2000 testing period, site A (about 8 ha) included country activity area, lake, boating area and part of natural resource landscape; site B (about 12 ha) included Sun plaza, creation garden and part of natural resource landscape; site C (about $12 \mathrm{ha}$ ) included culture of indigenous people's area, grass skiing field and part of natural resource landscape. The testing area covers about $90 \%$ of landfilling except management center and wastewater treatment factory. The vegetations in the sites $\mathrm{A}, \mathrm{B}$, and $\mathrm{C}$ were grass and small trees during the testing periods 1999-2000. The major vegetations were Centipede grass (Eremochlora ophiuroides) and Carpet grass (Axonopus affinis) in sites A, B, and $\mathrm{C}$ during testing period 2006. There is a setup for $\mathrm{CH}_{4}$ gas extraction system and each year recovered $3442 \mathrm{t}$ of $\mathrm{CH}_{4}$, which should equivalent to $79.2 \mathrm{Gg}$ of $\mathrm{CO}_{2}$, while the recovered $\mathrm{CH}_{4}$ was burned and produced $10.2 \mathrm{Gg}$ of $\mathrm{CO}_{2}$ only. Soil samples were collected at $0-20 \mathrm{~cm}$ depth in different burial locations. Randomly three soil cores in each site were collected, sieved to $2 \mathrm{~mm}$ and stored at $4{ }^{\circ} \mathrm{C}$ before

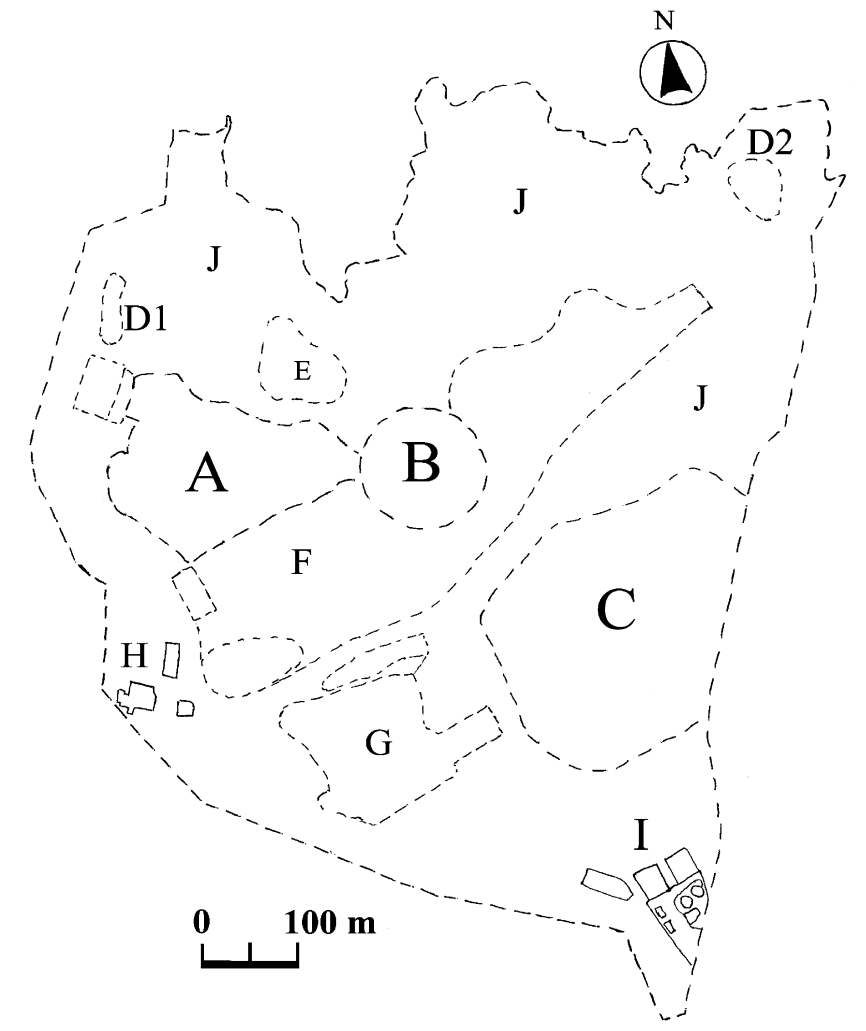

Fig. 1. Fu-Der-Kan closed landfill ( $37 \mathrm{ha}$ ) was reconstructed a multi-use recreational park: (A) country activity area $(2.6 \mathrm{ha})$, (B) Sun plaza (1.4 ha), (C) culture of indigenous people's area (5 ha), (D1) and (D2) slightly lake, (E) boating area $(0.8 \mathrm{ha}),(\mathrm{F})$ creation garden $(8 \mathrm{ha}),(\mathrm{G})$ grass skiing field (2 ha), $(\mathrm{H})$ management center, (I) wastewater treatment factory and (J) natural resource landscape (12 ha).

analysis. Each soil core was analyzed separately for moisture content, $\mathrm{pH}$ and organic carbon.

\subsection{Gas-type open-path FTIR spectroscopy measurement}

FTIR spectroscopy was used to measure the concentrations of atmospheric greenhouse gases at a height of $197 \mathrm{~cm}$ above ground with a scan number of 100 for $7 \mathrm{~min}$. Absorbance was read at wavenumber of $2999 \mathrm{~cm}^{-1}$ for $\mathrm{CH}_{4}$ and peak area from 2239 to $2393 \mathrm{~cm}^{-1}$ for $\mathrm{CO}_{2}$. The distance between the light source and the reflecting mirror was $35 \mathrm{~m}$ (for four chambers) or $100 \mathrm{~m}$ (for nine chambers). The details of the experimental set-up adopted for the FTIR spectroscopy method have been described in a previous paper (Chang et al., 2000). Because the interferometer characteristics are dominated by a high spectral resolution up to $0.06 \mathrm{~cm}^{-1}$ and a configuration suitable for field measurements was needed, the MB-104 (BOMEM, Hartmann and Braun, Canada) was used for radiation emission as well as absorption measurements. The spectrum was observed on a PC screen and the mirror was adjusted to optimize the signal. The absorption peak areas and atmospheric concentrations of $\mathrm{CH}_{4}$ and $\mathrm{CO}_{2}$ have high correlation coefficients (0.998-0.999 and 0.996-0.997, respectively) with distance between 0 and $100 \mathrm{~m}$. The accuracy of FTIR spectroscopy in $\mathrm{CH}_{4}$ and $\mathrm{CO}_{2}$ measurement is within $2 \%$ and $3 \%$, 
respectively. The atmospheric concentrations of greenhouse gases were determined from long-path measurements by differential absorption and a least squares fit of measurement, and were simulated by modeling air transmittances for various absorbed concentrations.

\section{3. $\mathrm{CH}_{4}$ and $\mathrm{CO}_{2}$ emission rates}

Gas samples were collected using a homemade closed acrylic chamber (length $40 \mathrm{~cm}$, width $40 \mathrm{~cm}$, height $65 \mathrm{~cm}$, volume about $96 \mathrm{~L}$ ) equipped with a fan, a thermometer, and a sampling hole. Either four or nine acrylic chambers were installed on the various landfill soils along a linear path. The chambers were inserted into the soil to a depth of $5 \mathrm{~cm}$ and allowed to equilibrate for $10 \mathrm{~min}$ before each measurement. Gas samples $(35 \mathrm{ml})$ were collected from the headspace of each chamber and transferred to a $12.6 \mathrm{ml}$ serum bottle sealed with a butyl rubber stopper and previously flushed with oxygen-free nitrogen gas (Yang and Chang, 1997). Gas samples were collected from chamber at 0.0, 0.5 , and $1.0 \mathrm{~h}$. Samples were taken again at 3.0, 3.5, and $4.0 \mathrm{~h}$ for comparison. $\mathrm{CH}_{4}$ and $\mathrm{CO}_{2}$ emission rates were calculated by performing a linear regression on the differences in $\mathrm{CH}_{4}$ and $\mathrm{CO}_{2}$ concentrations and adjusting for chamber volume and area covered. The following equation was used for the calculation (Rolston, 1986; Hegde et al., 2003):

$f=\left(\frac{V}{A}\right)\left(\frac{\Delta C}{\Delta t}\right)$

where, $f=\mathrm{CH}_{4}$ or $\mathrm{CO}_{2}$ emission rate $\left(\mathrm{mg} \mathrm{m}^{-2} \mathrm{~h}^{-1}\right), V=$ volume of chamber above the soil $\left(\mathrm{m}^{3}\right), A=$ cross-section of chamber $\left(\mathrm{m}^{2}\right), \Delta C=$ concentration difference between time zero and time $t\left(\mathrm{mg} \mathrm{m}^{-3}\right)$, and $\Delta t=$ time duration between two sampling periods $(\mathrm{h})$.

The ratios of atmospheric $\mathrm{CH}_{4}$ and $\mathrm{CO}_{2}$ concentrations measured with GC method to those measured with FTIR spectroscopy were analyzed. Gas samples were collected from the center of the FTIR spectrometer line at a height of $197 \mathrm{~cm} . \mathrm{CH}_{4}$ was analyzed by a Shimadzu 14A GC (Shimadzu Co., Japan) with a glass capillary column $(0.26 \mathrm{~mm} \times 2 \mathrm{~m})$ packed with Porapak Q $(80 / 100 \mathrm{mesh})$ and a flame ionization detector. The column temperature was set at $100{ }^{\circ} \mathrm{C}$ and the injection and the detector temperatures were set at $130{ }^{\circ} \mathrm{C}$. $\mathrm{CH}_{4}$ concentration was calculated with a standard curve from 0.1 to $100 \mathrm{ppm}$, with a detection limit of $0.01 \mathrm{ppm}$ (Yang and Chang, 1997). For $\mathrm{CO}_{2}$ analysis, a thermal conductivity detector was used. The column temperature was set at $150{ }^{\circ} \mathrm{C}$ and the injection and the detector temperatures were set at $200^{\circ} \mathrm{C}$. $\mathrm{CO}_{2}$ concentration was calculated using a standard curve from 0.1 to $1000 \mathrm{ppm}$, with a detection limit of $0.05 \mathrm{ppm}$ (Chang and Yang, 2003).

\subsection{Analytical methods}

Air and soil temperatures were determined on site either directly or under at $10 \mathrm{~cm}$ depth with a $\mathrm{Hg}$-thermometer.
Wind speed was measured with a weathercock (Weather link 4.0, USA). Light intensity was detected with a Toshiba SPI-5 photometer. Soil $\mathrm{pH}$ was determined using a $\mathrm{pH}$ meter directly in the soil or in a 1:1 (w/v) soil to water suspension. Moisture content was measured by drying the samples at $105^{\circ} \mathrm{C}$ for $24 \mathrm{~h}$ until a constant weight was achieved. Total organic carbon (TOC) was estimated using a TOC-5000A analyzer (Code HI 8424C, Shimadzu, Japan). Experiments were carried out in quadruplicate; while nine experiments were used in the measurement of $\mathrm{CH}_{4}$ and $\mathrm{CO}_{2}$ emission rates on June 30, 2000. Data were subjected to coefficient of variance analysis and Duncan's multiple range tests $(p=0.05)$ using the Statistical Analysis System (SAS Institute, 2002).

\section{Results}

\subsection{Properties of cover soils}

The properties of cover soil at different burial locations are shown in Table 1. The cover soils were acidic $(\mathrm{pH} 5.6-$ 6.0) in 1999 and 2000, and they were neutral (pH 7.4-7.7) after the construction of a multi-use recreational park in 2006. There were significant $\mathrm{pH}$ differences between 1999-2000 and $2006(p<0.05)$. The soil moisture, soil temperature and TOC in 2006 were lower than those in 19992000.

\section{2. $\mathrm{CH}_{4}$ and $\mathrm{CO}_{2}$ concentrations and emission rates at site $A$}

Air temperature, atmospheric concentrations of $\mathrm{CH}_{4}$ and $\mathrm{CO}_{2}$ at site $\mathrm{A}$ are presented in Fig. 2. Atmospheric concentrations of $\mathrm{CH}_{4}$ and $\mathrm{CO}_{2}$ on October 30, 1999 ranged from 1.7 to $2.7 \mathrm{ppm}$ and from 324 to $390 \mathrm{ppm}$, respectively. Average values were $2.2 \pm 0.3$ and $366 \pm 24 \mathrm{ppm}$, respectively. On November 24, 1999, atmospheric concentrations of $\mathrm{CH}_{4}$ and $\mathrm{CO}_{2}$ ranged from 1.9 to $4.6 \mathrm{ppm}$ and from 373 to $409 \mathrm{ppm}$, respectively, with average values of $3.1 \pm 0.9$ and $386 \pm 11 \mathrm{ppm}$, respectively. Atmospheric concentrations of $\mathrm{CH}_{4}$ and $\mathrm{CO}_{2}$ on October 30 were lower than those on November 24 and it might be due to the high wind velocity on October $30\left(4.2 \pm 0.7 \mathrm{~m} \mathrm{~s}^{-1}\right)$ (Table 1). Further, the total organic $\mathrm{C}$ content of cover soil on November 24, 1999 in site A was about 25\% lower than that on October 30, 1999 might be due to the construction as a multi-use recreation park during this period, and some new cover materials with low organic $\mathrm{C}$ content were layered on the surface. Therefore, both the organic $\mathrm{C}$ content of cover soil and the $\mathrm{CH}_{4}$ emission on November 24, 1999 were lower than those on October $30,1999 . \mathrm{CH}_{4}$ and $\mathrm{CO}_{2}$ emission rates ranged from $8.8 \pm 0.3$ to $21.7 \pm 4.3 \mathrm{mg} \mathrm{m}^{-2} \mathrm{~h}^{-1}$ and from $495 \pm 31$ to $1012 \pm 43 \mathrm{mg} \mathrm{m}^{-2} \mathrm{~h}^{-1}$, respectively (Table 1). $\mathrm{CH}_{4}$ emission rate was higher on October 30 , 1999 than those on November 24, 1999 because of high soil organic $\mathrm{C}$ and moisture content for active microbial reaction. 
Table 1

Properties of cover soils in Fu-Der-Kan landfill and after as the multi-use recreational park

\begin{tabular}{|c|c|c|c|c|c|c|c|c|c|}
\hline $\begin{array}{l}\text { Sampling } \\
\text { date }\end{array}$ & $\mathrm{pH}$ & $\begin{array}{l}\text { Moisture } \\
\text { content } \\
(\%)\end{array}$ & $\begin{array}{l}\text { Soil } \\
\text { temp. } \\
\left({ }^{\circ} \mathrm{C}\right)\end{array}$ & $\begin{array}{l}\text { Atmos. } \\
\text { pressure } \\
(\mathrm{Pa})\end{array}$ & $\begin{array}{l}\text { Humidity } \\
(\%)\end{array}$ & $\begin{array}{l}\text { Wind } \\
\text { velocity } \\
\left(\mathrm{m} \mathrm{s}^{-1}\right)\end{array}$ & $\begin{array}{l}\text { Organic } \\
\text { carbon } \\
(\%)\end{array}$ & $\begin{array}{l}\mathrm{CH}_{4} \text { emission } \\
\text { rate } \\
\left(\mathrm{mg} \mathrm{m}^{-2} \mathrm{~h}^{-1}\right)\end{array}$ & $\begin{array}{l}\mathrm{CO}_{2} \text { emission } \\
\text { rate } \\
\left(\mathrm{mg} \mathrm{m}^{-2} \mathrm{~h}^{-1}\right)\end{array}$ \\
\hline \multicolumn{10}{|l|}{ Site A } \\
\hline Oct. 30, 1999 & $5.5-6.1^{\mathrm{b}}$ & $31.1 \pm 1.7^{\mathrm{a}}$ & $31.9 \pm 1.0^{\mathrm{a}}$ & $1015 \pm 1^{\mathrm{a}}$ & $74.4 \pm 6.1^{\mathrm{a}}$ & $4.2 \pm 0.7^{\mathrm{b}}$ & $20.8 \pm 1.4^{\mathrm{a}}$ & $21.7 \pm 2.4^{\mathrm{b}}$ & $1012 \pm 14^{\mathrm{a}}$ \\
\hline Nov. 24, 1999 & $5.5-6.2^{\mathrm{b}}$ & $29.6 \pm 1.8^{\mathrm{a}}$ & $30.9 \pm 1.0^{\mathrm{a}}$ & $1014 \pm 1^{\mathrm{a}}$ & $79.3 \pm 7.8^{\mathrm{a}}$ & $2.3 \pm 0.9^{\mathrm{a}}$ & $15.4 \pm 1.0^{\mathrm{b}}$ & $8.8 \pm 0.3^{\mathrm{c}}$ & $495 \pm 11^{b}$ \\
\hline Jan. 3, 2006 & $7.6-7.7^{\mathrm{a}}$ & $19.6 \pm 2.2^{\mathrm{c}}$ & $20.5 \pm 0.8^{\mathrm{c}}$ & $1018 \pm 4^{\mathrm{a}}$ & $73.7 \pm 6.4^{\mathrm{a}}$ & $3.0 \pm 1.6^{\mathrm{a}}$ & $2.0 \pm 0.2^{\mathrm{c}}$ & $0.7 \pm 0.4^{\mathrm{d}}$ & $95 \pm 6^{c}$ \\
\hline \multicolumn{10}{|l|}{ Site B } \\
\hline Oct. 30, 1999 & $5.1-6.2^{\mathrm{b}}$ & $24.0 \pm 0.3^{\mathrm{b}}$ & $31.1 \pm 1.0^{\mathrm{a}}$ & $1015 \pm 1^{\mathrm{a}}$ & $74.4 \pm 6.1^{\mathrm{a}}$ & $4.2 \pm 0.7^{\mathrm{b}}$ & $14.7 \pm 1.7^{\mathrm{b}}$ & $12.8 \pm 0.2^{\mathrm{c}}$ & $901 \pm 15^{\mathrm{a}}$ \\
\hline Nov. 24, 1999 & $5.3-6.3^{\mathrm{b}}$ & $29.3 \pm 2.2^{\mathrm{a}}$ & $26.9 \pm 0.6^{\mathrm{b}}$ & $1014 \pm 1^{\mathrm{a}}$ & $79.3 \pm 7.8^{\mathrm{a}}$ & $2.3 \pm 0.9^{\mathrm{a}}$ & $19.3 \pm 2.2^{\mathrm{a}}$ & $35.0 \pm 3.1^{\mathrm{b}}$ & $813 \pm 17^{\mathrm{a}}$ \\
\hline May $11-13,2000$ & $5.3-6.4^{\mathrm{b}}$ & $26.5 \pm 3.0^{\mathrm{b}}$ & $29.5 \pm 2.3^{\mathrm{a}}$ & $1007 \pm 1^{b}$ & $62.7 \pm 6.5^{\mathrm{b}}$ & $2.4 \pm 1.2^{\mathrm{a}}$ & $19.7 \pm 3.0^{\mathrm{a}}$ & $18.4 \pm 2.2^{\mathrm{b}}$ & $1531 \pm 23^{\mathrm{a}}$ \\
\hline Jan. 4, 2006 & $7.2-7.7^{\mathrm{a}}$ & $17.5 \pm 1.0^{\mathrm{c}}$ & $20.6 \pm 0.7^{\mathrm{c}}$ & $1018 \pm 4^{\mathrm{a}}$ & $73.7 \pm 6.4^{\mathrm{a}}$ & $3.0 \pm 1.6^{\mathrm{a}}$ & $2.3 \pm 0.2^{\mathrm{c}}$ & $-0.1 \pm 0.4^{\mathrm{d}}$ & $20 \pm 5^{\mathrm{e}}$ \\
\hline \multicolumn{10}{|l|}{ Site $\mathrm{C}$} \\
\hline June 30,2000 & $5.6-6.3^{\mathrm{b}}$ & $33.6 \pm 2.9^{\mathrm{a}}$ & $33.6 \pm 2.1^{\mathrm{a}}$ & $1007 \pm 1^{b}$ & $71.1 \pm 7.4^{\mathrm{a}}$ & $1.5 \pm 0.8^{\mathrm{a}}$ & $20.7 \pm 4.0^{\mathrm{a}}$ & $163.3 \pm 7.7^{* \mathrm{a}}$ & $1349 \pm 16^{* \mathrm{a}}$ \\
\hline Jan. 5, 2006 & $7.3-7.6^{\mathrm{a}}$ & $22.5 \pm 2.0^{\mathrm{c}}$ & $20.0 \pm 0.9^{c}$ & $1018 \pm 4^{\mathrm{a}}$ & $73.7 \pm 6.4^{\mathrm{a}}$ & $3.0 \pm 1.6^{\mathrm{a}}$ & $2.6 \pm 0.5^{\mathrm{c}}$ & $0.2 \pm 0.2^{\mathrm{d}}$ & $-32 \pm 7^{\mathrm{d}}$ \\
\hline
\end{tabular}

Means $\pm \mathrm{SD}\left(n=4,{ }^{*} n=9\right)$. Emission rate was measured by chamber method. Values in the same column that do not share the same alphabetic superscript are significantly different at $5 \%$ level according to Duncan's multiple range tests.

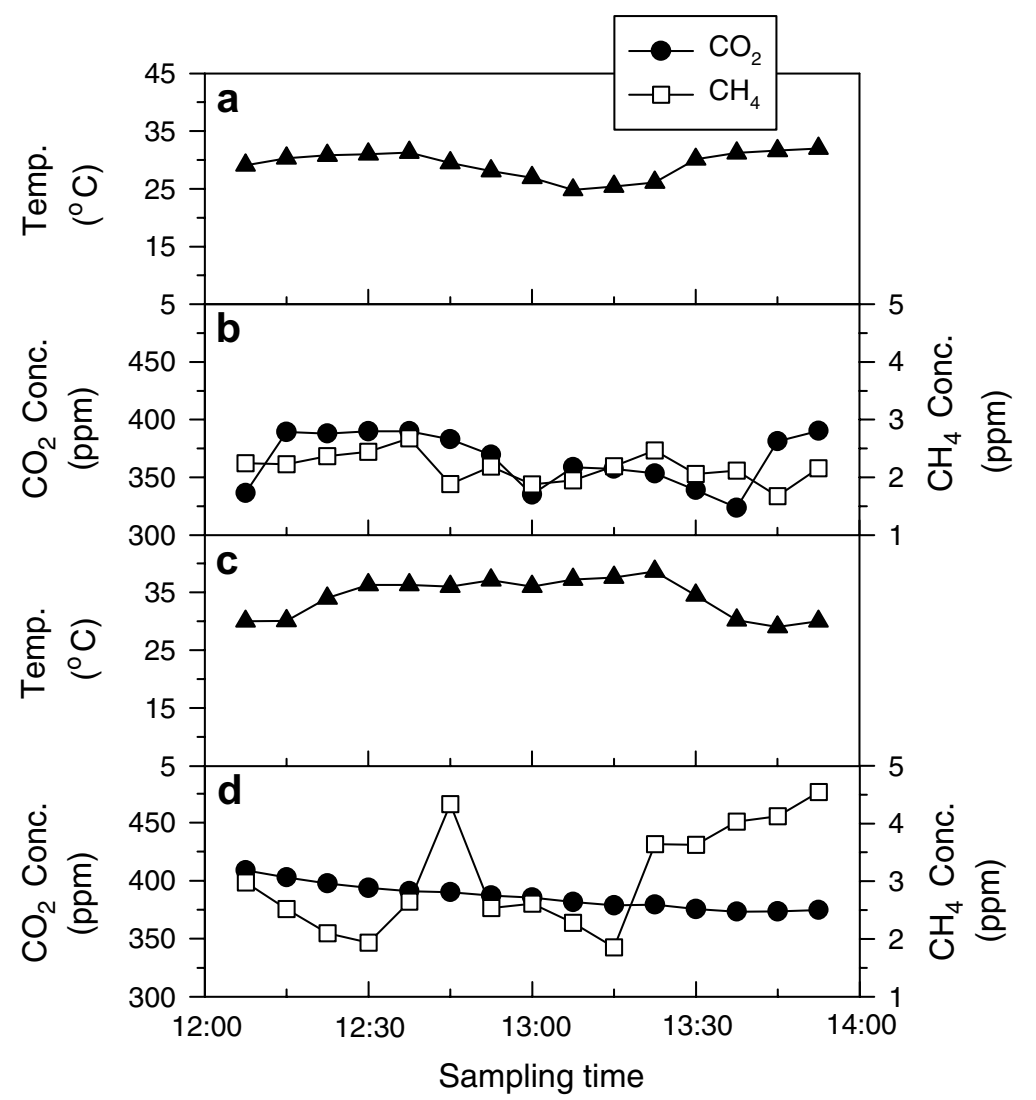

Fig. 2. Air temperature and atmospheric concentrations of $\mathrm{CO}_{2}$ and $\mathrm{CH}_{4}$ measured with FTIR spectroscopy at site A of the Fu-Der-Kan closed landfill. Data are presented for (a-b) October 30, 1999 and (c-d) November 24, 1999: (a) and (c) air temperature; (b) and (d) atmospheric concentrations of $\mathrm{CO}_{2}$ and $\mathrm{CH}_{4}$.

Site A was subsequently converted into a country activity area during the period from 1999 to 2003. Atmospheric concentrations of $\mathrm{CH}_{4}$ on January 4, 2006 were between 1.8 and $3.1 \mathrm{ppm}$, with an average of $2.3 \pm 0.5 \mathrm{ppm} . \mathrm{CO}_{2}$ on that date ranged from 373 to $441 \mathrm{ppm}$, with an average of $396 \pm 23 \mathrm{ppm}$. $\mathrm{CH}_{4}$ and $\mathrm{CO}_{2}$ emission rates were
$-0.4 \pm 0.3$ to $2.3 \pm 0.6 \mathrm{mg} \mathrm{m}^{-2} \mathrm{~h}^{-1}$ and $-72 \pm 17$ to $301 \pm 5 \mathrm{mg} \mathrm{m}^{-2} \mathrm{~h}^{-1}$, respectively. Average $\mathrm{CH}_{4}$ and $\mathrm{CO}_{2}$ emission rate was $0.7 \pm 0.4$ and $95 \pm 6 \mathrm{mg} \mathrm{m}^{-2} \mathrm{~h}^{-1}$, respectively (Fig. 3a-c). $\mathrm{CH}_{4}$ and $\mathrm{CO}_{2}$ emission rates in 2006 were lower than those in 1999 because of the more stable burial waste, low soil organic $\mathrm{C}$ and low moisture content. 


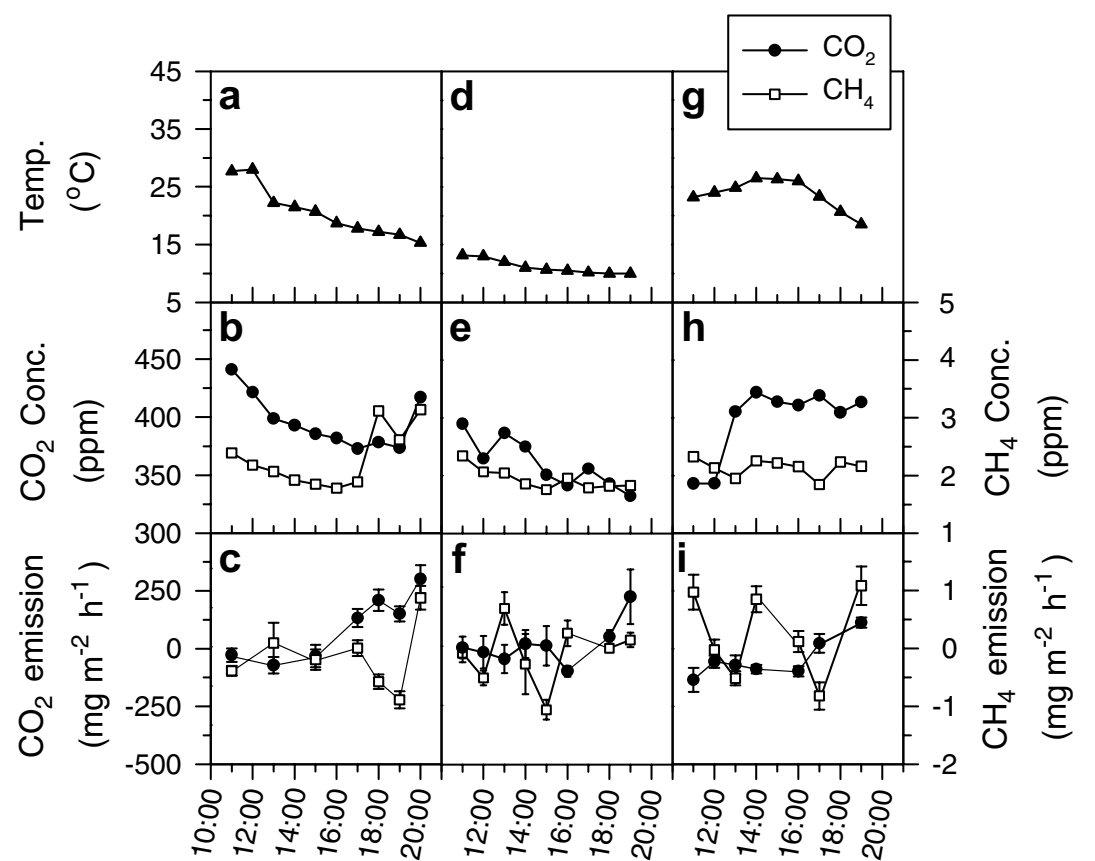

\section{Sampling time}

Fig. 3. Air temperature, atmospheric concentrations and emission rates of $\mathrm{CO}_{2}$ and $\mathrm{CH}_{4}$ of the Fu-Der-Kan landfill after as the multi-use recreational park. (a-c) country activity area on January 4, 2006. (d-f) Sun plaza on January 5, 2006. (g-i) culture of indigenous people's area on January 12, 2006. (a), (d) and (g) air temperature; (b), (e) and (h) atmospheric concentrations of $\mathrm{CO}_{2}$ and $\mathrm{CH}_{4}$; (c), (f) and (i) $\mathrm{CO}_{2}$ and $\mathrm{CH}_{4}$ emission rates.

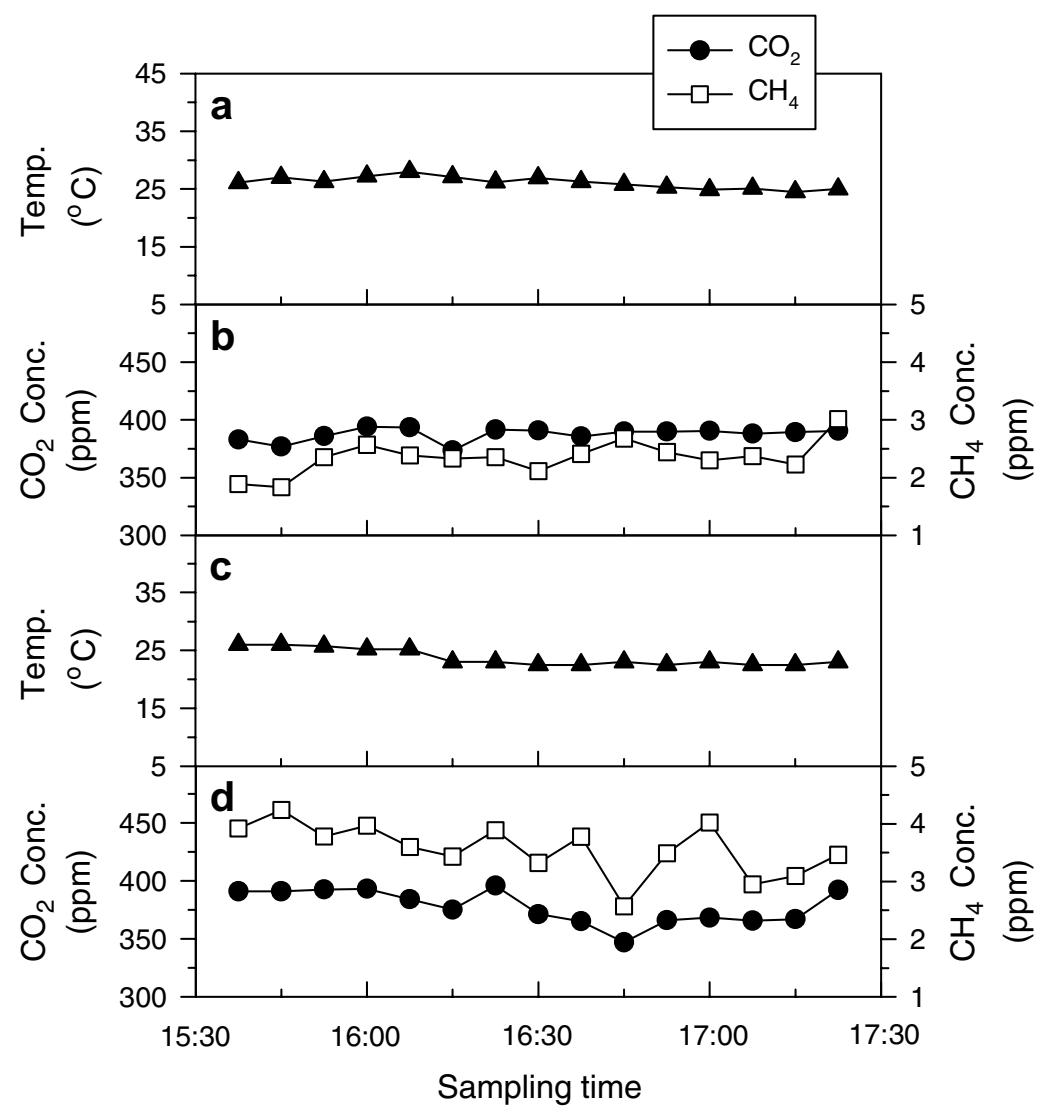

Fig. 4. Air temperature, and atmospheric concentrations of $\mathrm{CO}_{2}$ and $\mathrm{CH}_{4}$ measured with FTIR spectroscopy at site B of the Fu-Der-Kan closed landfill. Data are presented for (a-b) October 30, 1999 and (c-d) November 24, 1999: (a) and (c) air temperature; (b) and (d) atmospheric concentrations of $\mathrm{CO}_{2}$ and $\mathrm{CH}_{4}$. 
3.3. $\mathrm{CH}_{4}$ and $\mathrm{CO}_{2}$ concentrations and emission rates at site $B$

Air temperature, atmospheric concentrations of $\mathrm{CH}_{4}$ and $\mathrm{CO}_{2}$ at site $\mathrm{B}$ are shown in Fig. 4. Atmospheric $\mathrm{CH}_{4}$ concentrations on October 30, 1999 ranged from 1.8 to $3.0 \mathrm{ppm}$, with an average of $2.4 \pm 0.3 \mathrm{ppm}$. $\mathrm{CO}_{2}$ concentrations were between 373 and $394 \mathrm{ppm}$, with an average of $388 \pm 6$ ppm. On November 24, 1999, atmospheric $\mathrm{CH}_{4}$ and $\mathrm{CO}_{2}$ concentrations were ranged from 2.6 to $4.2 \mathrm{ppm}$, and from 347 to $397 \mathrm{ppm}$, respectively, with an average of $3.6 \pm 0.5$ and $378 \pm 15 \mathrm{ppm}$, respectively. $\mathrm{CH}_{4}$ and $\mathrm{CO}_{2}$ emission rates were $12.8 \pm 0.2$ to $35.0 \pm 3.1 \mathrm{mg} \mathrm{m}^{-2} \mathrm{~h}^{-1}$ and $813 \pm 17$ to $901 \pm 15 \mathrm{mg} \mathrm{m}^{-2} \mathrm{~h}^{-1}$, respectively (Table 1). Both the atmospheric concentration and emission rate of $\mathrm{CH}_{4}$ were high on November 24, 1999, which may be partly attributed to high soil organic $\mathrm{C}$ and moisture content. Different situations, in contrast to site A, were found in site B on November 24, 1999. The new cover material used in site B on November 24, 1999 might contain high organic $\mathrm{C}$. Therefore, both the organic $\mathrm{C}$ content of cover soil and the $\mathrm{CH}_{4}$ emission in site B on November 24, 1999 were higher than those on October 30, 1999.

Sun plaza was constructed at site $\mathrm{B}$ during the years 1999 to 2003. Atmospheric $\mathrm{CH}_{4}$ and $\mathrm{CO}_{2}$ concentrations on January 5, 2006 ranged from 1.8 to $2.3 \mathrm{ppm}$ and from 332 to $395 \mathrm{ppm}$, respectively. Average values were $1.9 \pm 0.2$ and $361 \pm 12 \mathrm{ppm}$, respectively. $\mathrm{CH}_{4}$ emission rate was $-1.1 \pm 0.5$ to $0.6 \pm 0.5 \mathrm{mg} \mathrm{m}^{-2} \mathrm{~h}^{-1}$ and $\mathrm{CO}_{2}$ emission rate was $-98 \pm 11$ to $224 \pm 38 \mathrm{mg} \mathrm{m}^{-2} \mathrm{~h}^{-1}$. Average $\mathrm{CH}_{4}$ and $\mathrm{CO}_{2}$ emission rates were $-0.1 \pm 0.4$ and $20 \pm 3 \mathrm{mg} \mathrm{m}^{-2} \mathrm{~h}^{-1}$, respectively (Fig. $3 \mathrm{~d}-\mathrm{f}$ ). These values were lower than those in 1999 because of the more stable buried refuse, low soil organic $\mathrm{C}$ and moisture content.

\section{4. $\mathrm{CH}_{4}$ and $\mathrm{CO}_{2}$ concentrations and emission rates at site $C$}

The $\mathrm{CH}_{4}$ emission rate $\left(163.3 \pm 7.7 \mathrm{mg} \mathrm{m}^{-2} \mathrm{~h}^{-1}\right)$ and $\mathrm{CO}_{2}$ emission rate $\left(1349 \pm 16 \mathrm{mg} \mathrm{m}^{-2} \mathrm{~h}^{-1}\right)$ at site $\mathrm{C}$ were the highest of the three sites and the variation among the nine installed chambers was also large (Table 1). The elevated $\mathrm{CH}_{4}$ and $\mathrm{CO}_{2}$ emission rates were due to new MSW was buried in this site during 1999.

Site $\mathrm{C}$ was converted into a culture of indigenous people's area during the years 2001 to 2003. Atmospheric $\mathrm{CH}_{4}$ concentrations were 1.9 to $2.3 \mathrm{ppm}$, with an average of $2.1 \pm 0.2 \mathrm{ppm}$ on January $12,2006 . \mathrm{CO}_{2}$ concentrations ranged from 343 to $422 \mathrm{ppm}$ with an average of $397 \pm 13$ ppm. $\mathrm{CH}_{4}$ and $\mathrm{CO}_{2}$ emission rates were $-0.8 \pm$ 0.7 to $1.1 \pm 0.5 \mathrm{mg} \mathrm{m}^{-2} \mathrm{~h}^{-1}$ and $-135 \pm 8$ to $113 \pm$ $15 \mathrm{mg} \mathrm{m}^{-2} \mathrm{~h}^{-1}$, respectively. Average $\mathrm{CH}_{4}$ and $\mathrm{CO}_{2}$ emission rates were $0.2 \pm 0.2$ and $-32 \pm 7 \mathrm{mg} \mathrm{m}^{-2} \mathrm{~h}^{-1}$, respectively (Figs. $3 \mathrm{~g}-\mathrm{i}$ ). $\mathrm{CH}_{4}$ emission rates were in the same level as those in sites A and B.

\subsection{Diurnal variation of atmospheric $\mathrm{CH}_{4}$ and $\mathrm{CO}_{2}$ concentrations and emission rates at site $B$}

Fig. 5 shows the diurnal variations in air temperature, atmospheric concentrations and emission rates of $\mathrm{CH}_{4}$ and $\mathrm{CO}_{2}$ from May 11 to 13,2000 at site B. The atmospheric $\mathrm{CH}_{4}$ concentrations ranged from 1.3 to $3.8 \mathrm{ppm}$ with an average of $2.7 \pm 0.8 \mathrm{ppm}$. The concentration of

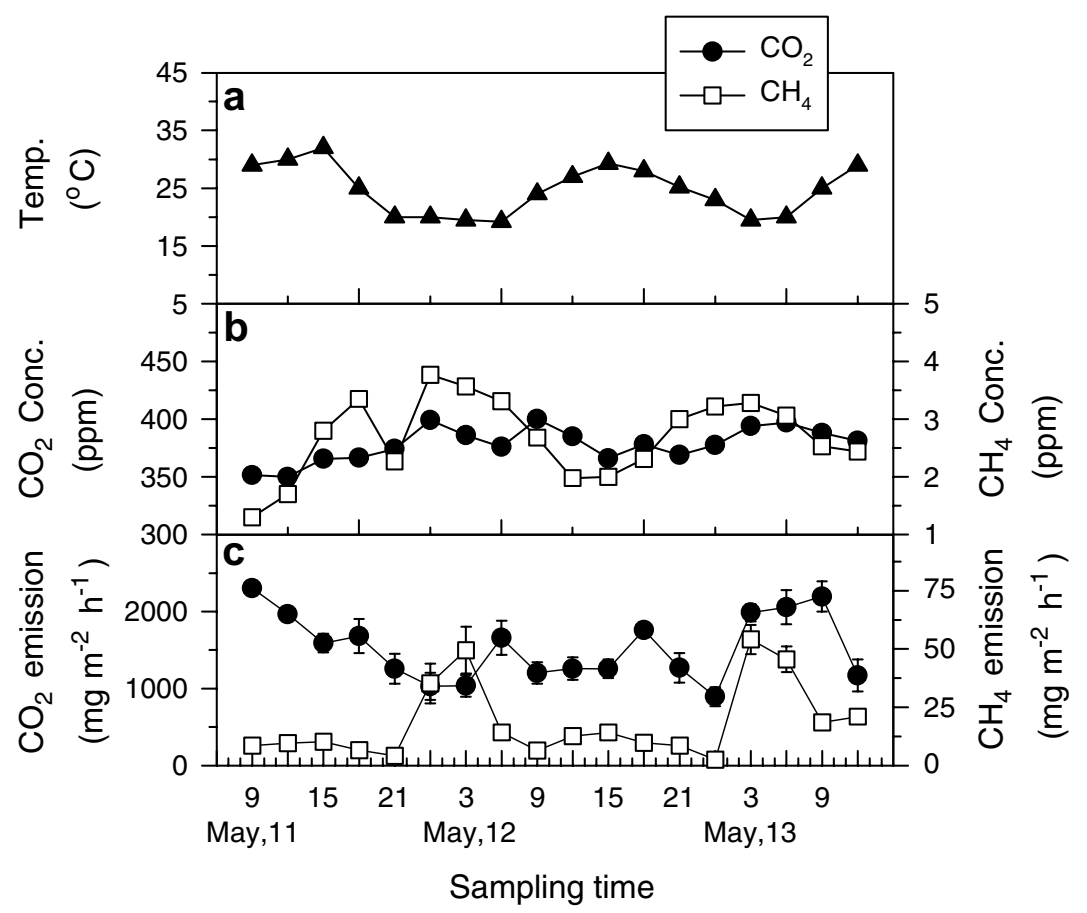

Fig. 5. Diurnal variation in the atmospheric concentrations and emission rates of $\mathrm{CO}_{2}$ and $\mathrm{CH}_{4}$ at site $\mathrm{B}$ in the Fu-Der-Kan closed landfill during May 11 to 13, 2000: (a) air temperature; (b) atmospheric concentrations of $\mathrm{CO}_{2}$ and $\mathrm{CH}_{4}$ measured with FTIR spectroscopy; (c) $\mathrm{CO}_{2}$ and $\mathrm{CH}_{4}$ emission rates. 
$\mathrm{CH}_{4}$ was high at night, which correlates with $\mathrm{CH}_{4}$ emission rate. The atmospheric $\mathrm{CO}_{2}$ concentration averaged at $374 \pm 15 \mathrm{ppm}$ and ranged from 350 to $399 \mathrm{ppm}$. The air temperature was the highest $\left(31.7^{\circ} \mathrm{C}\right)$ at noon on May 11 and the lowest $\left(19.5^{\circ} \mathrm{C}\right)$ at night on May 12 .

The average $\mathrm{CH}_{4}$ emission rate at site $\mathrm{B}$ was $18.4 \pm 3.3 \mathrm{mg} \mathrm{m}^{-2} \mathrm{~h}^{-1}$ (Table 1). The maximum rate was $54.1 \mathrm{mg} \mathrm{m}^{-2} \mathrm{~h}^{-1}$ at 3 a.m. on May 13 , and the minimum rate was $2.5 \mathrm{mg} \mathrm{m}^{-2} \mathrm{~h}^{-1}$ at midnight on May 12 . The average $\mathrm{CO}_{2}$ emission rate was $1531 \pm 23 \mathrm{mg} \mathrm{m}^{-2} \mathrm{~h}^{-1}$. The maximum rate was $2302 \mathrm{mg} \mathrm{m}^{-2} \mathrm{~h}^{-1}$ at 9 a.m. on May 11, and the minimum rate was $893 \mathrm{mg} \mathrm{m}^{-2} \mathrm{~h}^{-1}$ at midnight on May 12.

The diurnal variation in $\mathrm{CO}_{2}$ emission was very consistent after completion of the recreational park for country activity area, Sun plaza and culture of indigenous people's area in January 2006. The $\mathrm{CO}_{2}$ emission rates were high at night because of daytime photosynthetic activity by the grass and small trees. The diurnal variation of $\mathrm{CH}_{4}$ emission was insignificant due to the low organic matter content and more stable burial waste.

\section{Discussion}

Compared to other terrestrial ecosystems, landfills are characterized by a high rate of $\mathrm{CH}_{4}$ production and large $\mathrm{CH}_{4}$ gradients from the deeper production zones to the soil-atmosphere interface. Bogner et al. (1999) found that $\mathrm{CH}_{4}$ concentration was low at the surface and increased by about two orders of magnitude at $100 \mathrm{~m}$ depth. In paddy fields, the $\mathrm{CH}_{4}$ emission rate has been found to be high at 11 a.m. to 2 p.m. and low in the early morning due to the shallow of rice root and the high effect of soil temperature (Yang and Chang, 1999, 2001). In contrast, the $\mathrm{CH}_{4}$ emission rate at the closed Fu-Der-Kan landfill was the greatest at night for the collection of emission gases and $\mathrm{CH}_{4}$ at daytime. A similar phenomenon was also observed at the Shan-Chu-Ku landfill during years $1-2$, 2-3 and 5 (Hegde et al., 2003). However, no significant diurnal variation of emission rate was observed in the park constructed at the Fu-Der-Kan landfill. There was little fluctuation of soil temperature in the deeper zone of landfill.

$\mathrm{CH}_{4}$ and $\mathrm{CO}_{2}$ emission rates depend on soil $\mathrm{pH}$, moisture content, pressure, total organic carbon, kind and age of the burial waste, gas extraction system, kind and depth of soil cover and methane oxidation. $\mathrm{CH}_{4}$ and $\mathrm{CO}_{2}$ emission rates were the highest in the site $\mathrm{C}$ because of new MSW was buried during 1999. $\mathrm{CH}_{4}$ and $\mathrm{CO}_{2}$ emission rates were higher in site A on October 30, 1999 than those on November 24, 1999 due to high organic C and moisture content for active microbial reaction.

$\mathrm{CH}_{4}$ and $\mathrm{CO}_{2}$ emissions in the park varied widely and included negative values. Negative $\mathrm{CH}_{4}$ emission resulted from a net oxidation of atmospheric $\mathrm{CH}_{4}$ by indigenous $\mathrm{CH}_{4}$ oxidizing microbes. $\mathrm{CO}_{2}$ emission was negative due to net photosynthetic use of $\mathrm{CO}_{2}$ by grass and small trees.
Atmospheric concentrations and emission rates of $\mathrm{CH}_{4}$ and $\mathrm{CO}_{2}$ were lower in 2006 than those in 1999 and 2000. This might be due to more stable buried refuse and low organic C content (2.0-2.6\% in 2006 vs. $14.7-20.8 \%$ in 1999-2000). The fluctuation of $\mathrm{CH}_{4}$ emission rates ( -1.1 to $2.3 \mathrm{mg} \mathrm{m}^{-2} \mathrm{~h}^{-1}$ ) was minor in 2006. The $\mathrm{CO}_{2}$ emission rate was low in the daytime due to photosynthesis and it increased at night.

Hegde et al. (2003) measured the greenhouse gas concentrations in a homogenous grassland at the National Taiwan University campus, and found no major differences in the ratios of the concentrations measured with the GC method to those measured with FTIR spectroscopy (ratio is 1.10 in $\mathrm{CH}_{4}$ and 1.02 in $\mathrm{CO}_{2}$ ). However, the ratios of atmospheric $\mathrm{CH}_{4}$ concentration measured with $\mathrm{GC}$ method to those measured with FTIR spectroscopy in the Shan-Chu-Ku landfill were 2.28-4.78, 2.82-8.05, and $1.72-7.57$ at sites $1-2,2-3$, and 5 years old, respectively. The ratio decreased with the increasing of burial period. In this study, the ratios of atmospheric $\mathrm{CH}_{4}$ concentration in the closed landfill during 1999-2000 were 1.08-1.55 at site A, $1.06-1.75$ at site $\mathrm{B}$, and $1.21-2.47$ at site $\mathrm{C}$. The ratios had decreased to $0.96-1.16,0.97-1.15$, and 0.99 1.25 in 2006 for the country activity area, Sun plaza and culture of indigenous people's area, respectively. These values were lower than those in the Shan-Chu-Ku landfill because of the more stable organic matter of buried refuse. Furthermore, the ratios at the reconstructed areas in 2006 were close to those in the campus grassland, which had the same level of soil organic $\mathrm{C}$ content. Therefore, the ratio of atmospheric $\mathrm{CH}_{4}$ concentration measured with $\mathrm{GC}$ method to FTIR spectroscopy depends on the organic C content and could be used as a parameter to assess the stability of the buried refuse.

The presence of water vapor interfered with the $\mathrm{CO}_{2}$ measurement by FTIR spectroscopy. $\mathrm{CO}_{2}$ concentration was suddenly dropped at 16:45 p.m. on November 24, 1999 for the increase of relative humidity from 81 to $91 \%$. While $\mathrm{CO}_{2}$ concentration increased at afternoon on January 12, 2006 for the decrease of relative humidity from 88 to $67 \%$. Therefore, the background of measurement and alignment are necessary to crosscheck the disturbances of relative humidity change on $\mathrm{CO}_{2}$ concentration.

Due to low organic $\mathrm{C}$ content, both the atmospheric concentration and emission rate of $\mathrm{CH}_{4}$ at the Fu-DerKan closed landfill were less than $10 \%$ of those at the Shan-Chu-Ku landfill (Hegde et al., 2003). The $\mathrm{CH}_{4}$ emission rate at the reconstructed areas in 2006 was less than $2 \mathrm{mg} \mathrm{m}^{-2} \mathrm{~h}^{-1}$ which was less than $5 \%$ of that measured at the Fu-Der-Kan closed landfill site in 1999-2000. Again, this might be due to low organic $\mathrm{C}$ content and more stable organic matter of buried refuse.

In conclusion, both gas-type open-path FTIR spectroscopy and GC chamber method have been successfully used to measure atmospheric concentrations and emission rates of greenhouse gases in a closed and reconstructed landfill. The Fu-Der-Kan landfill closed in 1995 and was 
reconstructed to form a multi-use recreational park during 1999 to 2003. Atmospheric concentrations and emission rates for $\mathrm{CH}_{4}$ were higher at night than the daytime during 1999 to 2000 . The $\mathrm{CH}_{4}$ concentrations and emission rates in the closed landfill and reconstructed park were less than $10 \%$ and $1 \%$ of those in the active landfill, respectively. A systematic and continuous study of greenhouse gas emissions from closed landfills provides information about the field degradation of MSW, which in turn will help in the design of future landfills.

\section{Acknowledgements}

The authors thank Professor E. H. Chang and Dr. I. C. Lin for their technical assistances, and the National Science Council of Taiwan for financial support (NSC 88-2811-Z002-0001, NSC 89-EPA-Z002-003 and NSC EPA-90FA17-03-90B040).

\section{References}

Bogner, J., Matthews, E., 2003. Global methane emissions from landfills: New methodology and annual estimates 1980-1996. Global Biogeochem. Cy., 17. Article No. 1065.

Bogner, J.E., Spokas, K.A., Burton, E.A., 1999. Temporal variations in greenhouse gas emissions at a midlatitude landfill. J. Environ. Qual. $28,278-288$.

Chang, T.C., Leo, Y.C., Yang, S.S., 2000. Determination of greenhouse gases by open path gas-type FTIR spectroscopy. Food Sci. Agri. Chem. 2, 7-14.

Chang, T.C., Yang, S.S., 2003. Methane emission from wetlands in Taiwan. Atmos. Environ. 37, 4551-4558.

Czepiel, P.M., Shorter, J.H., Mosher, B., Allwine, E., McManus, J.B., Harriss, R.C., Kolb, C.E., Lamb, B.K., 2003. The influence of atmospheric pressure on landfill methane emissions. Waste Mange. 23, $593-598$.
Environmental Protection Administration/Taiwan, 2007. Official Statistic Report-2006. Environmental Protection Administration, Taipei, Taiwan.

Hegde, U., Chang, T.C., Yang, S.S., 2003. Methane and carbon dioxide emissions from Shan-Chu-Ku landfill site in northern Taiwan. Chemosphere 52, 1275-1285.

Jang, H.D., Yang, S.S., 2001. Greenhouse gases emission from municipal solid wastes in the column bioreactor. J. Biomass Energy Soc. China 20, 101-112.

Kumar, S., Gaikwad, S.A., Shekdar, A.V., Kshirsagar, P.S., Singh, R.N., 2004. Estimation method for national methane emission from solid waste landfills. Atmos. Environ. 38, 3481-3487.

Meraz, R.L., Vidales, A.M., Dominguez, A., 2004. A fractal-like kinetics equation to calculate landfill methane production. Fuel 83, 73-80.

Rolston, D.E., 1986. Gas flux. In: Klute, A. (Ed.), Methods of Soil Analysis, second ed. American Society Agronomy and Soil Science Society, American Monograph No. 9, Wisconsin, USA, pp. 1103-1119.

SAS Institute., 2002. SAS/STAT user's Guide, Release 6.03 SAS, Inst. Cary., North Carolina, USA.

Simpson, I.J., Rowland, F.S., Meinardi, S., Blake, D.R., 2006. Influence of biomass burning during recent fluctuations in the slow growth of global tropospheric methane. Geophys. Res. Lett., 33. Article No. L22808.

US Environmental Protection Agency, 2002. Greenhouse Gases and Global Warming Potential Values. Excerpt from the Inventory of US Greenhouse Emissions and Sinks: 1990-2000. pp. 16. (http://www. epa.gov/globalwarming/publications/emissions).

US Environmental Protection Agency, 2006. Global Mitigation of Non$\mathrm{CO}_{2}$ Greenhouse Gas. 3. Landfill Sector. US Environmental Protection Agency, Washington DC, USA.

Yang, S.S., Chang, E.H., 1997. Effect of fertilizer application on methane production in paddy soils of Taiwan. Biol. Fert. Soils 25, 245-251.

Yang, S.S., Chang, H.L., 1998. Effect of environmental conditions on methane production and emission from paddy soil. Agri. Ecosyst. Environ. 69, 69-80.

Yang, S.S., Chang, H.L., 1999. Diurnal variation of methane emission from paddy fields at different growth stages of rice cultivation in Taiwan. Agri. Ecosyst. Environ. 76, 75-84.

Yang, S.S., Chang, H.L., 2001. Effect of green manure amendment and flooding on methane emission from paddy fields. Chemosphere: Global Change Sci. 3, 41-49. 